\title{
Effects of climate change on Europe-wide winter wheat and sunflower productivity
}

\author{
P. A. Harrison*, R. E. Butterfield \\ Environmental Change Unit, University of Oxford, 1a Mansfield Road, Oxford OX1 3TB, United Kingdom
}

\begin{abstract}
Spatially explicit crop models were developed from mechanistic principles to investigate the regional impacts of climate change. The approach highlights the spatial variability of crop responses to altered environmental conditions. The mechanistic nature of the models allows some confidence to be placed in the results that are produced under climate change scenarios. Two crop models have been constructed and applied across a large European region: EuroWheat (winter wheat) and EuroSunfl (sunflower). Model results were compared with observed phenology and yield across a variety of scales and found to capture the current spatial variability in wheat and sunflower productivity. Climate change scenarios from both equilibrium and transient general circulation model experiments were applied to each crop model. Wheat yields are predicted to increase throughout Europe for all climate change scenarios. Conversely, water-limited sunflower yields decrease in most regions and scenarios. More positive effects are predicted for winter wheat than sunflower due to a lower sensitivity to increased temperature and a higher sensitivity to elevated concentrations of $\mathrm{CO}_{2}$. The lowest yield increases for wheat and the largest yield decreases for sunflower are found in western Europe, whilst the most positive responses for both crops occur in central and eastern Europe. Predictions for southern Europe are highly sensitive both within the region and between the scenarios. The old generation of equilibrium climate change scenarios gives the worst predictions (lowest yield increases or highest yield decreases). More beneficial responses are observed for the new generation of transient scenarios for both wheat and sunflower. Area averaged results for Europe, based on the United Kingdom Meterorological Office transient experiment (UKTR), indicate a rate of increase in winter wheat yields of $0.2 \mathrm{t} \mathrm{ha}^{-1}$ decade ${ }^{-1}$ up to the $2020 \mathrm{~s}$ and $0.36 \mathrm{t} \mathrm{ha}^{-1}$ decade $\mathrm{e}^{-1}$ beyond. Smaller changes are predicted for sunflower: a rate of decrease of $0.05 \mathrm{tha}^{-1}$ decade $^{-1}$ up to the 2020 s followed by an increase of $0.05 \mathrm{tha}^{-1}$ decade $^{-1}$
\end{abstract}

KEY WORDS: Spatial crop modelling Climate change Winter wheat Sunflower

\section{INTRODUCTION}

Assessments using site- (small-) scale models of Europe's major crops are commonly used to analyse detailed physiological responses of crops to changes in climate on a daily time scale (Bindi et al. 1996, Semenov et al. 1996). Such models are developed from detailed information gained from specific experiments and aim to describe mechanistically the processes of crop development, growth and yield formation. The mechanistic approach of these models allows scientists

\footnotetext{
·E-mail: paula.harrison@ecu.ox.ac.uk
}

to have confidence in the results that they produce under climate change scenarios (Carter et al. 1994). On the other hand, large-scale modelling studies often rely on the use of semi-empirical indices to identify regions of crop suitability (Carter et al. 1991, Kenny \& Harrison 1992). Empirical models provide reliable predictions only within the boundaries of the variables from which they are constructed. This restricts their value for climate change impact assessment (Carter et al. 1994).

What is needed is a mechanistic-based approach for large scale modelling. It is not possible to simply apply site-specific crop models over large regions, such as the European continent, due to their requirement for detailed input data and local calibration. Previous 
studies have run models at sites which are considered representative of predefined homogeneous areas to derive regional changes in crop production (Wolf \& van Diepen 1991, Easterling et al. 1993, Papajorgji et al. 1994). The advantage of this approach is that detailed modelling techniques can be applied to the representative sites. The disadvantage is that little information on the spatial patterns of change can be determined. Such approaches may be appropriate in regions, such as the American Midwest, where there is little spatial variability in the environmental factors which affect crop growth. However, they are not suitable in Europe where there are no large homogeneous regions in terms of climate, soils and topography. Analysis of the climate of Europe by Orr \& Brignall (1995) showed that unique combinations of variables represent quite small areas and similar climates may not be geographically proximate.

This paper describes an alternative method for assessing the regional impacts of climate change using spatially explicit crop models which are based on mechanistic principles. This approach retains the spatial variability of crop responses across the European region, enabling investigation of bioclimatic shifts in crop productivity and identification of sensitive areas and changes in regional disparities. The mechanistic approach also produces more reliable predictions of responses to possible future changes in climate than previous empirically-based studies. In the final section of the paper, the models are applied to 3 climate change scenarios to predict possible changes in future wheat and sunflower productivity.

Two spatial crop models are described: EuroWheat (winter wheat) and EuroSunfl (sunflower). Winter wheat (Triticum aestivum L.) is an autumn sown long duration crop which is currently grown extensively throughout Europe. In contrast, sunflower (Helianthus annuus L.) is a spring sown crop with a much shorter growing period whose major areas of cultivation are presently restricted to southern and central Europe. The complexity of each model was dependent on data availability and the degree of existing knowledge for the particular crop. Sufficient information was available for wheat and sunflower to allow the prediction of phenological development, potential yield and waterlimited yield across Europe

\section{DATABASE DESCRIPTION}

A prerequisite to a mechanistic-based modelling approach is the availability of necessary climatic, edaphic and agronomic data over the region of interest. A spatial climatic database for Europe has been constructed at a resolution of $0.5^{\circ}$ latitude by $0.5^{\circ}$ lon- gitude (Hulme et al. 1995). This database contains monthly minimum, mean and maximum temperatures, precipitation, global radiation, relative humidity and wind speed for the 1961-1990 climatic normal. Daily minimum and maximum temperatures and radiation were estimated from monthly values using a sine curve interpolation routine (Brooks 1943). Errors associated with a number of methods for estimating daily climatic data from monthly values, including a sine curve interpolation routine, were evaluated in Harrison (1994) and found to be smail for the prediction of phenological development in wheat. Monthly estimates of potential evapotranspiration (PET) were calculated using the Penman method (Penman 1948). The available waterholding capacity of the soil was estimated using the methodology and database developed by Groenendijk (1989) at a $0.5^{\circ}$ latitude/longitude resolution. Agronomic data were obtained from the Food and Agriculture Organisation of the United Nations (FAO), Statistical Office of the European Communities (EUROSTAT) and from experiments reported in the literature. Statistics collated include yield, area planted and observed dates of developmental stages.

\section{MODEL DESCRIPTION}

EuroWheat and EuroSunfl are each divided into 4 linked submodels which predict sowing dates, phenological development, potential yield and water-limited yield. Each submodel is based on an existing site-specific mechanistic model or information taken from the literature.

\subsection{Sowing}

Sowing dates for both wheat and sunflower vary widely throughout Europe. To determine present and possible future optimal sowing dates in Europe a climatic criterion is required.

Winter wheat is an autumn-sown crop with a cool temperature requirement (vernalization) in its early development stages. In southern Europe there is a relatively short time period over which vernalization can take place and, thus, wheat is sown close to the time when vernalization will be most effective ( $M$. Bindi \& F. Miglietta pers. comm.). Vernalization of winter wheat occurs between -4 and $17^{\circ} \mathrm{C}$ with an optimum temperature range of 3 to $10^{\circ} \mathrm{C}$ according to the AFRCWHEAT model (Weir et al. 1984, Porter et al. 1987). Sowing time in the Eurowheat model is defined as the first day of autumn when the mean temperature is $11.75^{\circ} \mathrm{C}$ or lower. The value of $11.75^{\circ} \mathrm{C}$ is threequarters of the way between the maximum vernalizing 
temperature of $17^{\circ} \mathrm{C}$ and the beginning of the optimum range $\left(10^{\circ} \mathrm{C}\right)$. This assumes that temperatures will decrease sufficiently to be within the optimum vernalizing temperature range shortly after sowing. Predicted sowing dates agree well with observed sowing dates throughout Europe. In southern Finland, winter wheat is sown in late August/early September (Mukula \& Rantanen 1989). This corresponds with a simulated date in early September in the model. The average sowing date for winter wheat in The Netherlands and Hungary is mid-October ( $\mathrm{J}$. Wolf pers. comm., Z. Harnos pers. comm.) which fits with the predicted date. In Spain, Italy and Greece sowing dates vary from late October to early December, which also agree well with the climatic criterion (Narciso et al. 1992, Bindi et al. 1993).

Sunflower is a spring-sown crop which yields well with high radiation. Sowing is generally timed so that the growing season corresponds to the period of maximum radiation receipt at any location. This was represented in EuroSunfl by identifying the first day of spring when the mean temperature is $10^{\circ} \mathrm{C}$ or higher. A $10^{\circ} \mathrm{C}$ temperature threshold is confirmed by Narciso et al. (1992) as the optimal temperature for sowing. This criterion predicts a broad range of sowing dates in central and southern Europe from January to early May. Sowing in January and early February was considered to be an unrealistic management practice and a further constraint was added to fix the earliest possible date of sowing at 15 February. Predicted sowing dates from mid-February to mid-April in Spain, Italy and Greece are consistent with those reported in the literature (Narciso et al. 1992).

\subsection{Phenological development}

The phenological development submodel in EuroWheat is based on the AFRCWHEAT simulation model (Weir et al. 1984, Porter et al. 1987). It predicts wheat development through the interaction of thermal time, photoperiod and vernalization. Dates of emergence, floral initiation, double ridges, terminal spikelet, anthesis, beginning and end of grain filling and physiological maturity are calculated by the model on a daily time step. Input data are minimum and maximum temperature, sowing date and latitude.

The phenological development submodel in EuroSunfl is based on thermal time. Most cultivars of sunflower are classified as insensitive to photoperiod (A. Merrien pers. comm.) although it has been reported that both short and long days can accelerate sunflower development (Doyle 1975, Hammer et al. 1982, Goyne $\&$ Schneiter 1987, 1988). Flowering can occur over a wide range of daylengths and, hence, photoperiod was assumed to be inconsequential when predicting development over a wide range of locations (Kiniry et al. 1992). Dates of flowering and physiological maturity are calculated by the model on a daily time step. Input data are mean temperature and sowing date.

\subsection{Potential growth}

The potential growth submodel in Eurowheat is based on the Sirius simulation model (Jamieson \& Wilson 1988, Jamieson 1989, Jamieson et al. 1996). In EuroSunfl a similar, but slightly simpler, temperatureand radiation-based model is used. Final potential yield is accumulated by both models on a daily time step. Input data are minimum and maximum temperature, radiation, sowing date and phenological development stages.

Canopy development is modelled as a function of leaf area index (LAI). For wheat, LAI is calculated in 4 stages throughout the growing season: firstly, by an exponential function of thermal time from emergence to an LAI of 5; secondly, by a linear function of thermal time from an LAI of 5 to the maximum LAI of 8.5; thirdly, by a constant value from an LAI of 8.5 to anthesis; and finally, by a quadratic function of thermal time from anthesis to the end of grain filling. For sunflower LAI is calculated by an exponential function of thermal time up to a maximum LAI of 3 at anthesis after which it declines exponentially (based on Chapman et al 1993). The interception of radiation by the canopy is calculated from the downward light flux density at the top of the crop canopy, the LAI and an extinction coefficient ( $k$ ) (Monsi \& Saeki 1953). For wheat $k$ is fixed at 0.45 , whilst for sunflower $k$ is calculated by a power function of LAI throughout the growing season and is generally between 0.85 and 0.95 (Zaffaroni \& Schneiter 1989). Intercepted photosynthetically active radiation (PAR) is assumed to be $50 \%$ of the total intercepted radiation, to account for the use of global radiation input data. Dry matter is accumulated using a radiation use efficiency (RUE) of $2.2 \mathrm{~g} \mathrm{MJ}^{-1}$ for wheat and $2.0 \mathrm{~g} \mathrm{MJ}^{-1}$ for sunflower. Final yield is determined for wheat assuming all dry matter accumulated after anthesis is translocated to the grain plus $20 \%$ of the dry matter which has accumulated by anthesis. For sunflower, potential yield is calculated from total dry matter using a harvest index of 0.25 (Kiniry et al. 1992).

Elevated concentrations of atmospheric carbon dioxide have been found to increase the rate of photosynthesis for $C_{3}$ crops such as wheat and sunflower (Poorter 1993). This is included in the EuroWheat and EuroSunfl models through an increase in RUE with increasing $\mathrm{CO}_{2}$. Increases in RUE of 30 and $20 \%$ are used for wheat and sunflower, respectively, for a dou- 
bling of $\mathrm{CO}_{2}$ (Mitchell \& Lawlor 1993, J. R. Kiniry pers. comm.). A linear relationship is assumed for lower $\mathrm{CO}_{2}$ concentrations.

\subsection{Water limitations to growth}

The water-limited growth submodels in both EuroWheat and EuroSunfl are based on the FAO cropspecific water balance model (FAO 1986). Input data are the water-holding capacity of the soil, precipitation, potential evapotranspiration (PET), sowing date, phenological development and potential yield. Spatial precipitation data for Europe are available only at a monthly temporal resolution on the $0.5^{\circ}$ latitude/longitude grid. There are many problems and uncertainties in estimating daily precipitation from monthly totals. Hence, the water-limited growth model is run on a monthly time step.

Crop water requirements are calculated by adjusting PET according to the crop demand for water over a particular development stage, using a crop coefficient. Crop coefficients have been derived by the FAO (1986) for many crops from the ratio between potential and actual crop evapotranspiration. For winter wheat, the FAO (1986) report that crop coefficients are fixed at 0.3 throughout the period of winter dormancy. They begin to increase when the crop resumes active growth, reaching 1.0 when full crop cover is achieved. After anthesis coefficients fall to a value of 0.5 at maturity. The changes in the water demand of the crop reflect the expansion of leaf area through the growing season. Hence, in the EuroWheat model, crop coefficients are calculated by a linear function of LAI varying between 0.3 and 1.0 as LAI increases and between 1.0 and 0.5 as LAI decreases. For sunflower, the FAO (1986) report that crop coefficients increase from 0.3 at emergence to a maximum of 1.05 at flowering. After flowering they fall to a value of 0.4 at maturity. In the EuroSunfl model, crop coefficients are calculated by linear interpolation between these developmental stages at the daily time step. Coefficients are then averaged for each month. The difference between precipitation and available soil water is determined for successive crop phases to assess whether the soil is in deficit or surplus. Crop performance is resolved as the accumulated difference between crop water requirements and deficit expressed as a ratio of the total water requirement. The final output of the model is the water requirement satisfaction index (WRSI)

FAO (1986) relate the WRSI to the final yield of a crop based on the correspondence between the percentage of satisfaction of water requirements and the percentage of the maximum foreseeable yield for a given crop and location (Table 1). In this analysis, the calculation of potential yield is taken to represent the maximum possible yield for winter wheat and sunflower. The WRSI values and the FAO classification (Table 1) are used to adjust potential yield to account for water-limitations.

Elevated concentrations of atmospheric carbon dioxide have been found to decrease the transpiration rate of $C_{3}$ crops (Tyree \& Alexander 1993). This is incorporated in the EuroWheat and EuroSunfl models through an adjustment factor applied to the crop coefficients. Goudriaan \& Unsworth (1990) calculated a reduction in daily transpiration of 0.897 for $\mathrm{C}_{3}$ crops grown under doubled $\mathrm{CO}_{2}$. Hence, crop coefficients are reduced by $10 \%$ for a doubling of $\mathrm{CO}_{2}$ from 350 to 700 ppmv for both wheat and sunflower. This reflects an increased water use efficiency under elevated $\mathrm{CO}_{2}$. A linear relationship is assumed for lower $\mathrm{CO}_{2}$ concentrations.

\subsection{Other suitability constraints}

Selected components of different site-specific models were used in the development of the EuroWheat and EuroSunfl models in conjunction with information from the literature. These were sufficient to delimit the area of sunflower suitability, as this crop is mainly constrained by temperature in Europe (A. Merrien pers. comm.). However, for winter wheat it is necessary to incorporate 2 further constraints to suitability (severe winters and excessive rainfall).

The northern limit to successful winter wheat cultivation in Europe is in Finland, where it is grown in southern and southwestern regions between latitudes $60^{\circ}$ and $61^{\circ} 30^{\prime} \mathrm{N}$ (Mukula \& Rantanen 1989). Beyond this, significant crop losses occur from damage caused by ice and water during winter. The mean minimum January temperature at the margin of suitability in Finland is approximately $-11.5^{\circ} \mathrm{C}$. Hence, in EuroWheat the probability of significant crop losses due to winter damage is considered to be too great in areas with mean minimum January temperatures less than

Table 1. Classification of water-limited crop performance according to the FAO (1986). WRSI: water requirement satisfaction index

\begin{tabular}{|llc|}
\hline $\begin{array}{l}\text { \% yield in relation to } \\
\text { max. (potential) yield }\end{array}$ & Performance & WRSI \\
\hline$>100$ & Very good & 100 \\
$90-100$ & Good & $95-99$ \\
$50-90$ & Average & $80-94$ \\
$20-50$ & Mediocre & $60-79$ \\
$10-20$ & Poor & $50-59$ \\
$<10$ & Crop failure & $<50$ \\
\hline
\end{tabular}


$-11.5^{\circ} \mathrm{C}$. This identifies mid-and northern Scandinavia and much of Russia as being unsuitable for winter wheat cultivation due to severe winters.

In areas of excessive rainfall the probability of achieving effective establishment of winter wheat and its subsequent harvest is so low that the risks of crop failure outweigh any benefits of growing wheat (Russell \& Wilson 1994). Bunting et al. (1982) reported that wheat cultivation is generally prevented if mean annual precipitation is greater than $1000 \mathrm{~mm}$. However, such a constraint does not take into account the changes in evapotranspiration or soil moisture status that may occur with climate change. Hence, a constraint based on an accumulated soil water surplus throughout the period of crop establishment was developed and calibrated for the present situation against Bunting et al.'s precipitation threshold. This identifies western Norway, western Great Britain, western Ireland, northwestern Spain and western parts of the former Yugoslavia as being unsuitable for winter wheat cultivation due to excessive rainfall.

\section{CURRENT WHEAT AND SUNFLOWER PRODUCTIVITY}

The EuroWheat and EuroSunfl models predict development for a specified cultivar (cv.) across Europe. However, many different varieties of winter wheat and sunflower are cultivated in different regions of Europe depending on environmental conditions, local pests and diseases and management practices. Further, cultivars which are considered optimal for a region under the present climate may become sub-optimal with cli- mate change. Existing cultivars originating in other areas or entirely new cultivars may be more appropriate in the future. Thus, 6 winter wheat varieties (Table 2) and 3 sunflower varieties (Table 3) were modelled throughout Europe. Detailed results are described for 1 variety of each crop: $c v$. Avalon for winter wheat and cv. Cerflor for sunflower.

\subsection{Phenological development}

Dates of physiological maturity for winter wheat range from early June to late July in southern Europe and from late July to mid-August in central and northern Europe for the range of varieties. These predictions correspond with dates of maturity reported for 25 countries in the study region by Broekhuizen (1965), Bunting et al. (1982), Weir et al. (1984), Reinink et al. (1986), Crofts (1989), Narciso et al. (1992), Nonhebel (1993) and Russell \& Wilson (1994). The date of maturity for $\mathrm{cv}$. Avalon as predicted by the EuroWheat model is shown in Fig. 1a. Cv. Avalon is generally cultivated in northwestern Europe and EuroWheat predicts physiological maturity occurring from late July to early August in this region. However, cv. Avalon is a fast developing variety and slower developing varieties (i.e. cv. Riband, cv. Slepner and cv. Hustler, Table 2) from the same region are predicted to mature from early to mid-August. Modelled dates of double ridges and anthesis were also compared with observed dates reported in the literature. Spatial variations in the occurrence of each stage throughout Europe were reproduced by the EuroWheat model (see Harrison 1994).

Table 2. Details of modelled winter wheat varieties

\begin{tabular}{|llll|}
\hline Variety & $\begin{array}{l}\text { Region of model } \\
\text { calibration data }\end{array}$ & Cultivar characteristics & Source \\
\hline Avalon & UK & Fast developing & J. R. Porter (pers. comm.) \\
Riband & UK & Medium-fast developing & Semenov et al. (1993) \\
Slepner & UK & Slow developing & Semenov et al. (1993) \\
Hustler & UK & Slow developing & Weir et al. (1984) \\
Caribo & Netherlands & Slow developing & Reinink et al. (1986) \\
Alcala & Spain & Fast developing & M. A. Semenov (pers. comm.) \\
\hline
\end{tabular}

Table 3. Details of modelled sunflower varieties

\begin{tabular}{|llll|}
\hline Variety & $\begin{array}{l}\text { Region of model } \\
\text { calibration data }\end{array}$ & Cultivar characteristics & Source \\
\hline Cerflor & France & Early maturing & Merrien (1986) \\
Topflor & France & Late maturing & Merrien (1986) \\
Avante & UK & Very early maturing & V. Church (pers. comm.) \\
\hline
\end{tabular}




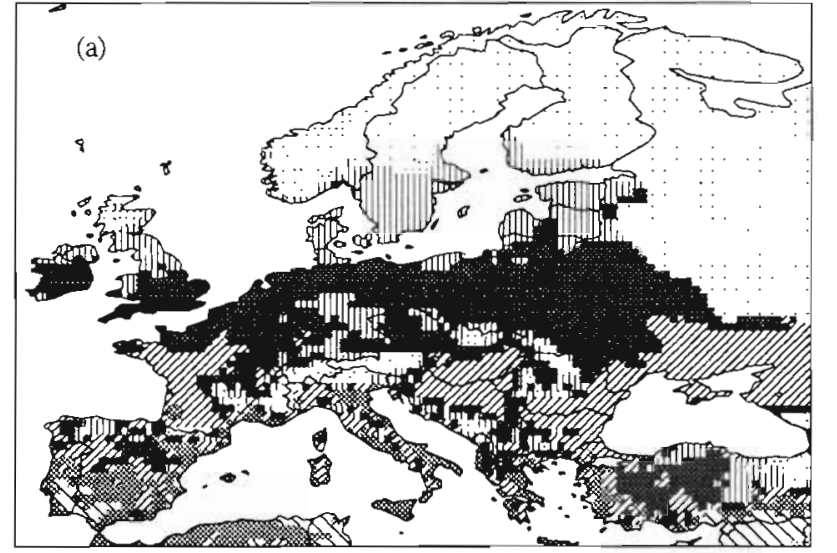

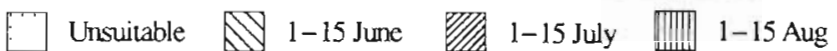

21-31 May 16-30 June 16-31 July

$16-31$ Aug
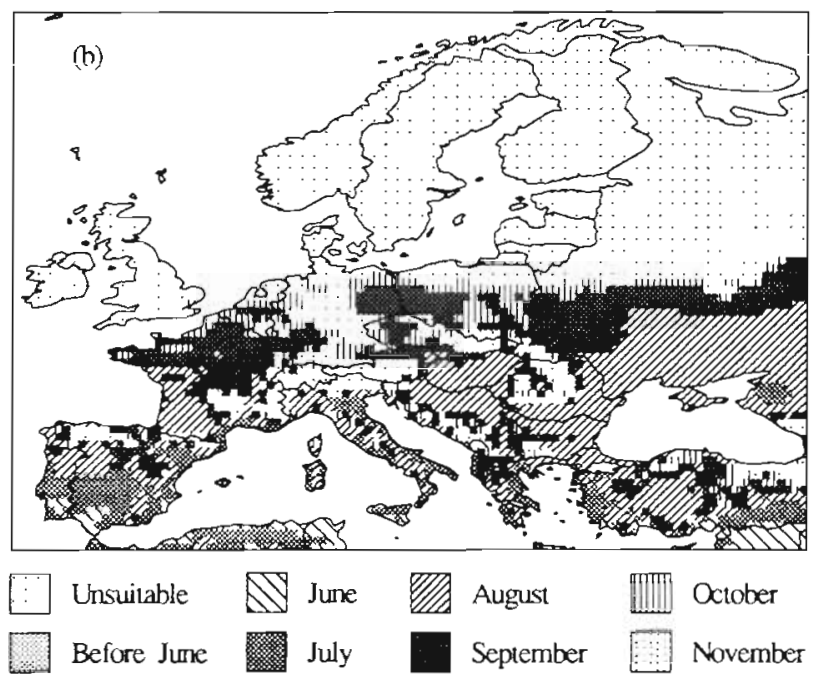

Fig. 1. Predicted date of maturity for the current climate (1961-1990): (a) winter wheat cv. Avalon and (b) sunflower cv. Cerflor

Sunflower maturity dates range from July in southern Europe to October in northern Europe for the 3 modelled varieties. Predictions are consistent with those reported in the main sunflower producing countries of Spain, France, Italy and Greece (Narciso et al. 1992, F. Michaux, Semences CARGILL, Saint-AmandLongpré, France, pers. comm., R. Slade, PANNAR (UK), Blandford, UK, pers. comm.). The date of maturity for $\mathrm{cv}$. Cerflor as predicted by the EuroSunfl model is shown in Fig. 1b. Cv. Cerflor is an early maturing French variety and EuroSunfl predicts maturity occurring from August to October in France. Later maturing varieties, such as cv. Topflor, are generally cultivated in southern France. Cv. Topflor is predicted to mature in September in this area. A comparison of modelled

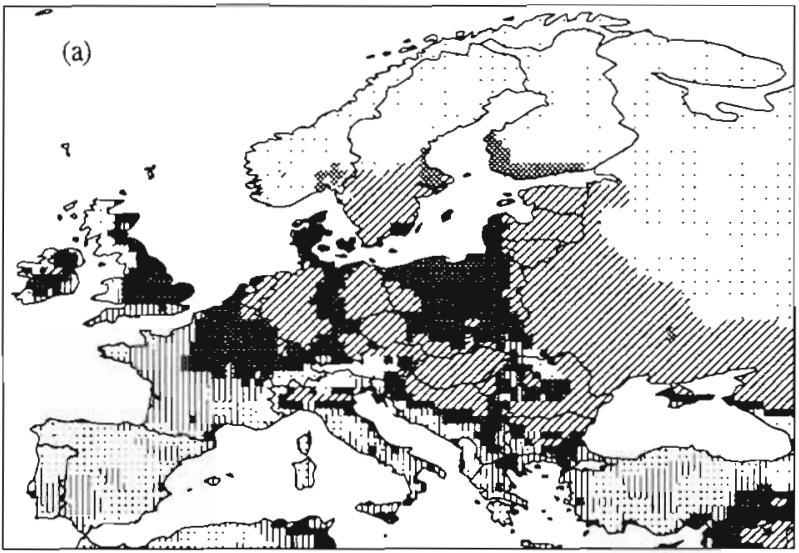

Unsuitable AY $6.0-7.0$ tha $8.0-9.0$ tha $<6.0$ tha $7.0-8.0$ tha $9.0-10.0$ tha $>11.0$ tha

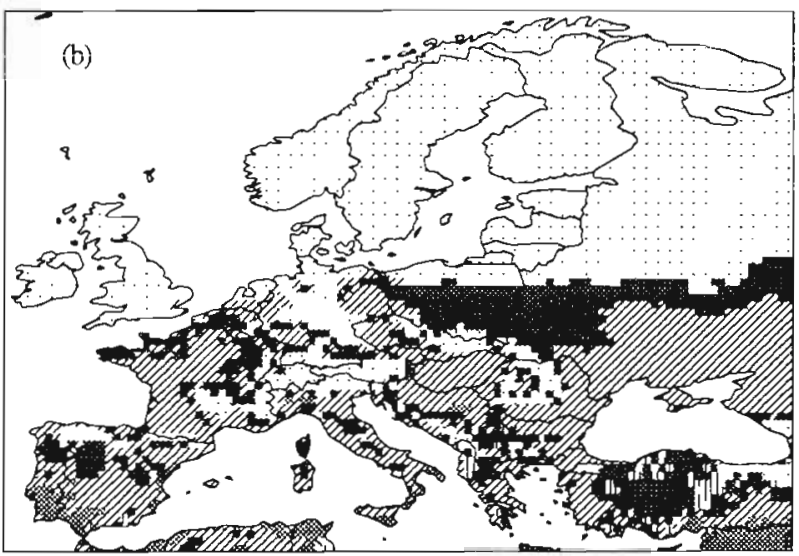

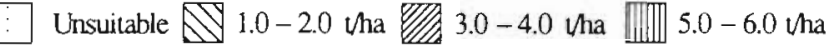
$<1.0$ tha $2.0-3.0$ tha $\square .0-5.0$ tha $\div 6.0$ tha

Fig. 2. Predicted potential yield for the current climate (1961-1990): (a) winter wheat cv. Avalon and (b) sunflower cv. Cerflor

and observed dates of flowering is described in Harrison et al. (1995).

\subsection{Potential yield}

The distribution of potential wheat yield for $\mathrm{cv}$. Avalon and potential sunflower yield for $\mathrm{cv}$. Cerflor is shown in Fig. 2. Potential wheat yields are highest in southern Europe, due to higher radiation receipts, where they are up to $12 \mathrm{t} \mathrm{ha}^{-1}$ and lowest in northeast Europe where they range from 7 to $10 \mathrm{t} \mathrm{ha}^{-1}$ Across most of central and northwest Europe potential yields of between 8 and $10.5 \mathrm{t} \mathrm{ha}^{-1}$ are predicted. Sunflower yields range from 2 to $5 \mathrm{t} \mathrm{ha}^{-1}$ for most of 


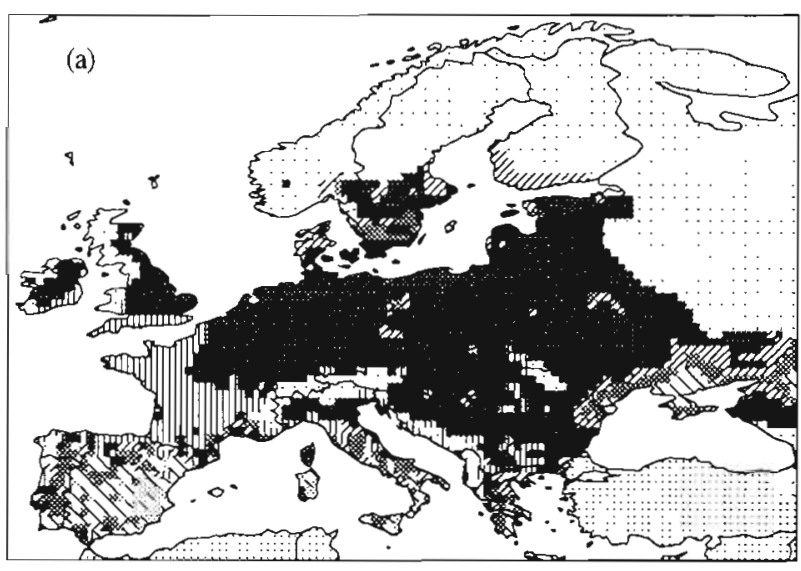

Unsuitable $2-4$ tha $6-8$ tha $<2$ tha $4-6$ tha $\square-10$ tha No data

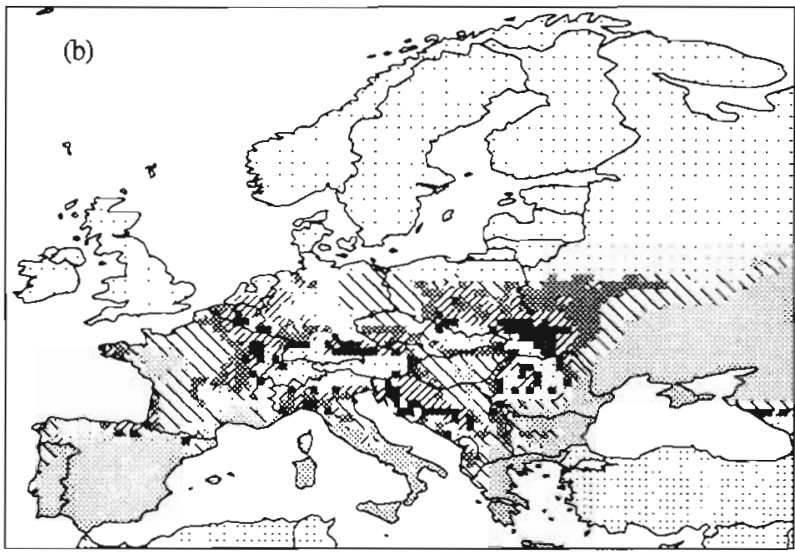

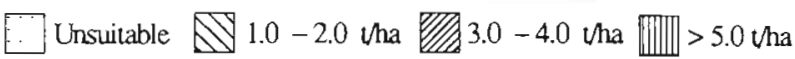
< 1.0 tha $2.0-3.0$ tha $4.0-5.0$ tha No data

Fig. 3. Predicted water-limited yield for the current climate (1961-90): (a) winter wheat cv. Avalon and (b) sunflower cv. Cerflor

Europe. The highest yields are predicted in continental central-eastern Europe where the growing season is long and radiation receipts during seed filling are high.

The predictions of potential growth correspond with expert opinion and statistics from experimental stations where optimal growing conditions have been maintained throughout the season. A winter wheat experiment at IACR-Rothamsted Experimental Station, UK, on cv. Avalon with full irrigation and nitrogen fertilization produced an average grain yield of $8.28 \mathrm{t}$ $\mathrm{ha}^{-1}$ in 1984-85 and 9.3 $\mathrm{t} \mathrm{ha}^{-1}$ in 1985-86 (Weir 1988, Barraclough et al. 1989). Russell \& Wilson (1994) state that wheat yields from high input farming systems now regularly exceed $10 \mathrm{tha}^{-1}$ in northwest Europe. These figures agree with the EuroWheat prediction for northwest Europe ( 8 to $10.5 \mathrm{t} \mathrm{ha}^{-1}$ ). A sunflower experiment conducted in Toulouse, France, under potential growing conditions produced irrigated yields of $4 \mathrm{t} \mathrm{ha}^{-1}$ in 1989 (Kiniry et al. 1992). Irrigated sunflower yields in Greece are reported to vary between 2.5 and $4 \mathrm{t} \mathrm{ha}^{-1}$ (Narciso et al. 1992). These observations are consistent with EuroSunfl predictions of 2 to $5 \mathrm{t} \mathrm{ha}^{-1}$ for Europe.

\subsection{Water-limited yield}

The WRSI predicts very good yields for winter wheat across most of central and northern Europe. This implies that there are no significant water limitations to wheat growth for the 1961-1990 climatic normal. In southern Europe the classification varies from mediocre to poor crop performance. This implies that only 10 to $50 \%$ of potential yield will be achieved without irrigation (Table 1). The distribution of waterlimited wheat yield for cv. Avalon is shown in Fig. 3a. The lowest water-limited wheat yields are predicted in southern Europe and vary from 1 to $5 \mathrm{t} \mathrm{ha}^{-1}$. In central and eastern Europe wheat yields range from 6 to $10 \mathrm{t}$ $\mathrm{ha}^{-1}$, whilst in northwest Europe yields of 8 to $10.5 \mathrm{t}$ $\mathrm{ha}^{-1}$ are predicted

For sunflower much of the area of current suitability is classified as water-limited to some extent according to the WRSI. Crop failure is predicted across most of Spain, southern Italy, Greece and the Ukraine. According to the FAO (1986) classification, this means that less than $10 \%$ of yield potential will be realised in these regions. In other areas the WRSI varies from poor to average crop performance, indicating that between 10 and $90 \%$ of potential yield may be achieved without irrigation. The distribution of water-limited sunflower yield for cv. Cerflor is shown in Fig. 3b. Across most of Spain, southern Italy, Greece and southern CIS predicted yields are less than $1 \mathrm{tha}^{-1}$. The best yields, of up to $5 \mathrm{t} \mathrm{ha}^{-1}$, are predicted in northern Italy, the shared border of Austria and Hungary, western Germany, and parts of Poland and Russia. All other suitable areas predict yields of between 2 and $4 \mathrm{tha} \mathrm{h}^{-1}$

Annual wheat and sunflower yield data were extracted from the FAO Praduction Yearbooks (19751990), EUROSTAT (1992) and national statistics (Finland: Yearbook of Farm Statistics 1986-1990; Sweden: Statistics Sweden 1975-1990; Denmark: Agricultural Statistics 1970-1990; United Kingdom: Agricultural Statistics - United Kingdom 1975-1990; The Netherlands: Agricultural Census 1975-1990; Italy, Spain and Greece: Narciso et al. 1992) to compare against predicted water-limited yields from EuroWheat and EuroSunfl. Unfortunately it was not possible to run the models to produce a 30 yr time series of yields from 
a)

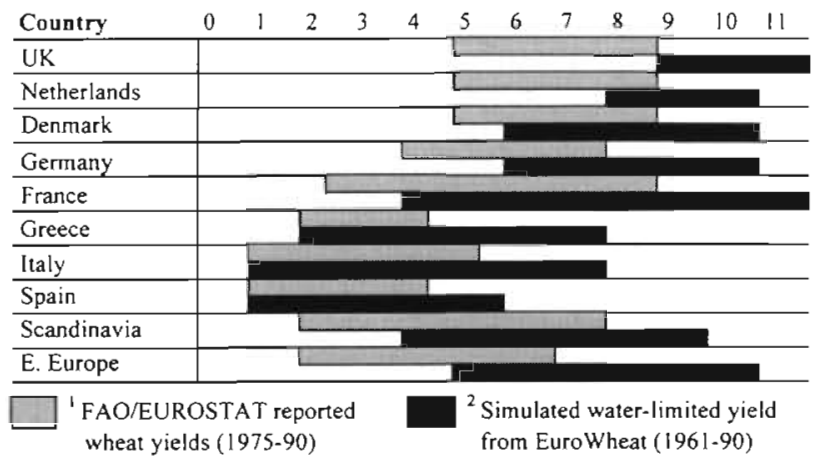

b)

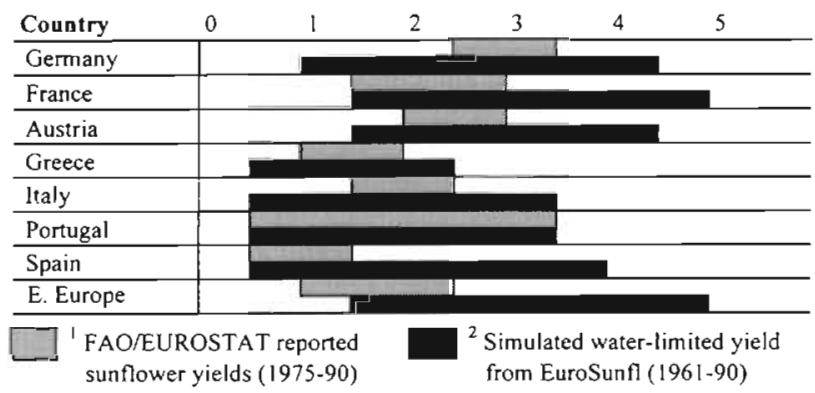

Fig. 4. Comparison of FAO and EUROSTAT reported yields and water-limited predicted yields for a range of European countries: (a) wheat; and (b) sunflower. 'Data compiled from agricultural surveys conducted within individual countries; ${ }^{2}$ range of simulated results in a country for the 1961-1990 climatic normal

1961 to 1990 to compare with this data because only time series of mean temperature and precipitation data are available in the gridded climatology of Hulme et al. (1995). Fig. 4 shows a comparison between FAO and EUROSTAT reported yields for the period 1975-1990 and EuroWheat/EuroSunfl predicted yields for selected European countries. Reported yields include dry matter losses due to stresses from nutrients, pests, diseases, etc., as well as from water and, hence, as expected are generally lower than predicted waterlimited yields for both crops. Most importantly, both models capture the correct spatial pattern of yield levels. The highest yields for wheat occur in northwestern
Europe and very low yields occur in southern Europe. This is confirmed by Russell \& Wilson (1994) who state that 3 of the top 10 wheat producing countries, in terms of tonnage, are France, the United Kingdom and Germany. A similar spatial pattern for water-limited sunflower yields is found with the highest yields occurring in northwestern and eastern Europe and much lower yields in southern Europe. The range of predicted yields is larger for sunflower than wheat compared with observed yields because the countries of northwestern Europe are marginal for production and limited reported data is available (e.g. Germany). Further, sunflowers are more extensively irrigated than wheat in southern Europe and, thus, observed yields can be greater than simulated EuroSunfl water-limited yields (e.g. Greece and Italy).

\section{THE EFFECTS OF CLIMATE CHANGE}

Current winter wheat and sunflower production is constrained in parts of northern Europe by cool summers and, in the case of winter wheat, cold winters. With climate change, increased temperatures may allow these crops to be cultivated in areas where they are currently unsuited. Further, changes in climate are likely to affect the productivity of both crops in regions where they are presently produced. These issues were examined using a number of sensitivity tests and scenarios of possible future climate change. Results from analysing the sensitivity of each sub-model to systematic changes in their input variables are described in Harrison et al. (1995). Results from applying 3 climate change scenarios are described in the following sections.

Scenarios were constructed from equilibrium and transient general circulation model (GCM) experiments using the methodology described by Barrow et al. (1996) (Table 4). Equilibrium experiments are used to analyse the response of climate to an instantaneous doubling of carbon dioxide $\left(\mathrm{CO}_{2}\right)$. The exact date that such a climate might be realised is unknown, but it is not expected before the latter years of the 21 st century at the earliest and probably not until the 22 nd century (Barrow \& Hulme 1995). The United Kingdom Meteor-

Table 4. Characteristics of the climate change scenarios applied to EuroWheat and EuroSunfl

\begin{tabular}{|lcccc|}
\hline Scenario & $\begin{array}{c}\text { Global-mean temperature } \\
\text { change }\left({ }^{\circ} \mathrm{C}\right)\end{array}$ & $\begin{array}{c}\text { Global-mean precipitation } \\
\text { change }(\%)\end{array}$ & $\begin{array}{c}\mathrm{CO}_{2} \text { concentration } \\
\text { (ppmv) }\end{array}$ & $\begin{array}{c}\text { Median year when changes } \\
\text { may be realised }\end{array}$ \\
\hline UKHI & 3.5 & 9 & 560 & early 2100 s \\
UKTR31-40 & 0.68 & 1.1 & 454 & 2023 \\
UKTR66-75 & 1.76 & 3.3 & 617 & 2064 \\
\hline
\end{tabular}


ological Office high resolution equilibrium experiment (UKHI; Mitchell et al. 1990) was adopted in this study. Transient experiments are more physically realistic and complex than equilibrium experiments. In such experiments concentrations of atmospheric $\mathrm{CO}_{2}$ are allowed to rise gradually over time. The United Kingdom Meteorological Office transient experiment (UKTR; Murphy 1995, Murphy \& Mitchell 1995) was analysed and 2 decadal time slices were selected: the Years $31-40$ as representative of the climate half way through the model experiment and the Years $66-75$ as the last decade of the experiment. These model decades were linked to the global-mean temperature changes associated with the Intergovernmental Panel on Climate Change (IPCC) IS92a greenhouse gas emissions scenario (Leggett et al. 1992). Approximate calendar years were assigned to the decades using a simple climate model (MAGICC; Wigley \& Raper 1992). By running MAGICC with the greenhouse gas emissions of IS92a and for a median climate sensitivity of $2.5^{\circ} \mathrm{C}$ the climate of the decade $31-40$ is estimated to occur in 2023 and that of decade $66-75$ in 2064 (Table 4).

Concomitant changes in atmospheric carbon dioxide were used in the potential and water-limited growth model runs for each climate change scenario. For the
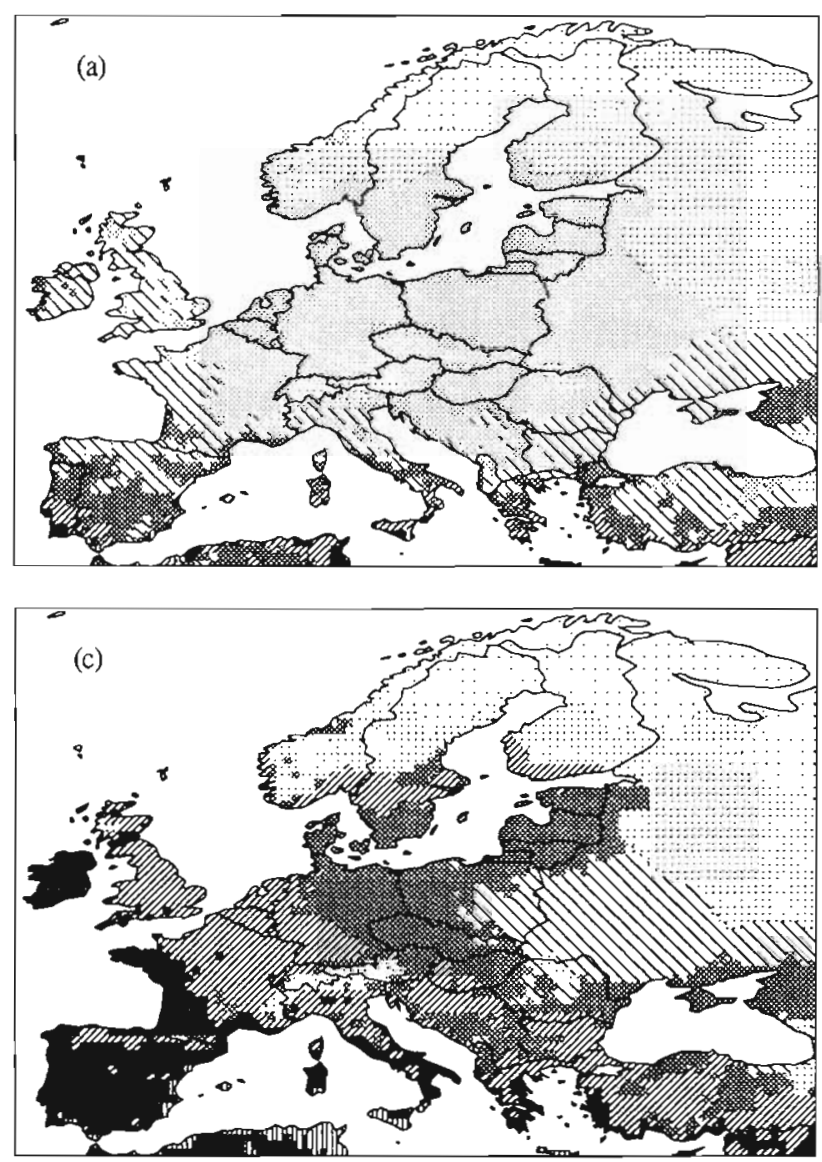

equilibrium scenario a $\mathrm{CO}_{2}$ concentration of 560 ppmv was assumed. For the transient scenarios $\mathrm{CO}_{2}$ concentrations were 454 ppmv for the earlier decade, 31-40, and 617 ppmv for the last decade, $66-75$.

\subsection{Phenological development}

All climate change scenarios cause faster rates of wheat and sunflower development, which shortens the length of the growing period. This would lead to an earlier start to crop growth in the spring and a shorter grain or seed filling period, resulting in reduced yield if management practices are not altered. The magnitude of the shortening of the growing period varies according to the crop and the increases in temperature projected by each scenario. The equilibrium scenario (UKHI) predicts the largest increases in temperature and, hence, produces the greatest reduction in growing period length for both crops (Figs. 5a \& 6a). The duration from sowing to maturity in southern Europe is reduced by 3 to $5 \mathrm{wk}$ for winter wheat and by 5 to $8 \mathrm{wk}$ for sunflower. In northern Europe a shortening of 4 to $8 \mathrm{wk}$ is observed for winter wheat and 9 to $11 \mathrm{wk}$ for sunflower. There is a strong north-south gradient in

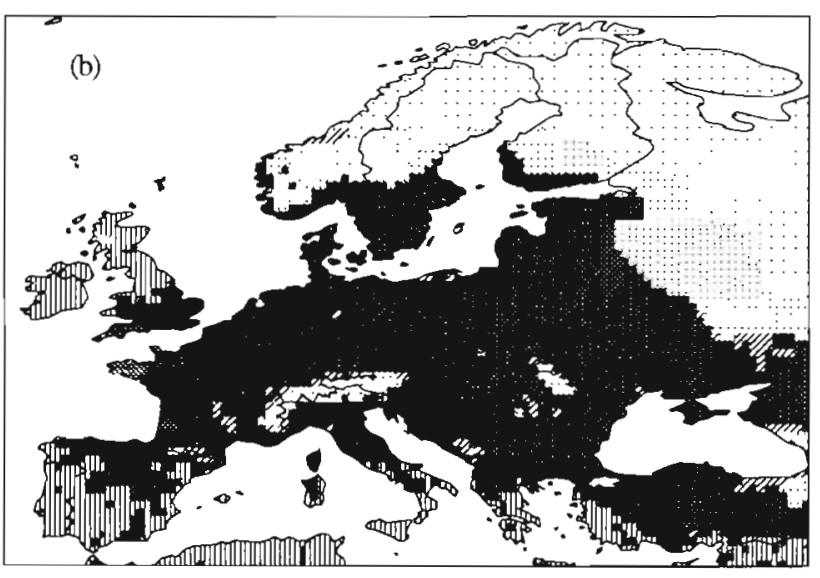

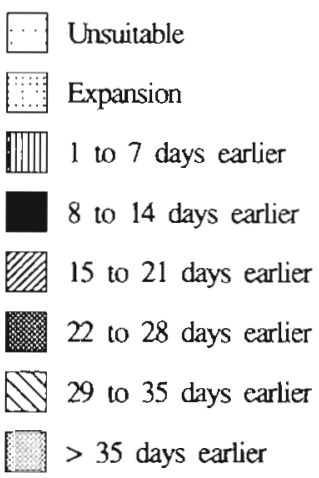

Fig. 5. Change in date of maturity for winter wheat cv. Avalon under 3 climate change scenarios: (a) UKHI, (b) UKTR31-40, and (c) UKTR66-75 

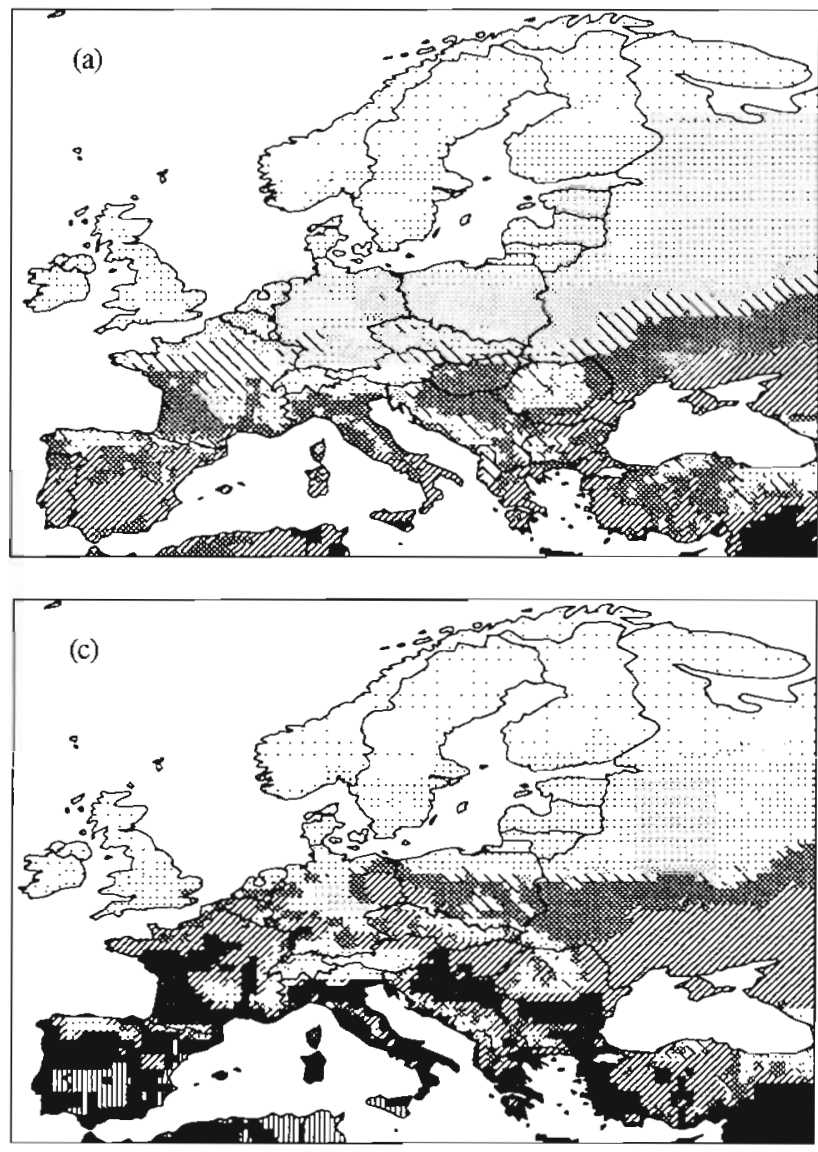

the change in the duration from sowing to maturity across Europe resulting in a more uniform timing of maturity dates for both crops. Both decades from the transient model (UKTR) predict lower increases in temperature than the equilibrium model and, thus, the shortening of the growing period is less severe. In the earlier decade $(31-40)$ the duration from sowing to maturity decreases by 1 to $2 \mathrm{wk}$ and 1 to $7 \mathrm{wk}$ across Europe for winter wheat and sunflower, respectively (Figs. 5b \& 6b), whilst in the last decade $(66-75)$ the duration for wheat shortens by 4 to 5 wk in eastern Europe and by 2 to $4 \mathrm{wk}$ in western Europe and for sunflower by 1 to 10 wk across Europe (Figs. 5c \& 6c).

Sunflower generally experiences much greater reductions in the length of the growing season than winter wheat. This is because wheat development is modelled through the interaction of thermal time with photoperiod and vernalization, whilst sunflower development is modelled on thermal time alone. This causes wheat development to be less sensitive than sunflower development to changes in temperature as both photoperiod and vernalization repress the thermal time response

An expansion in the area of suitability for winter wheat into northern and eastern Europe is predicted
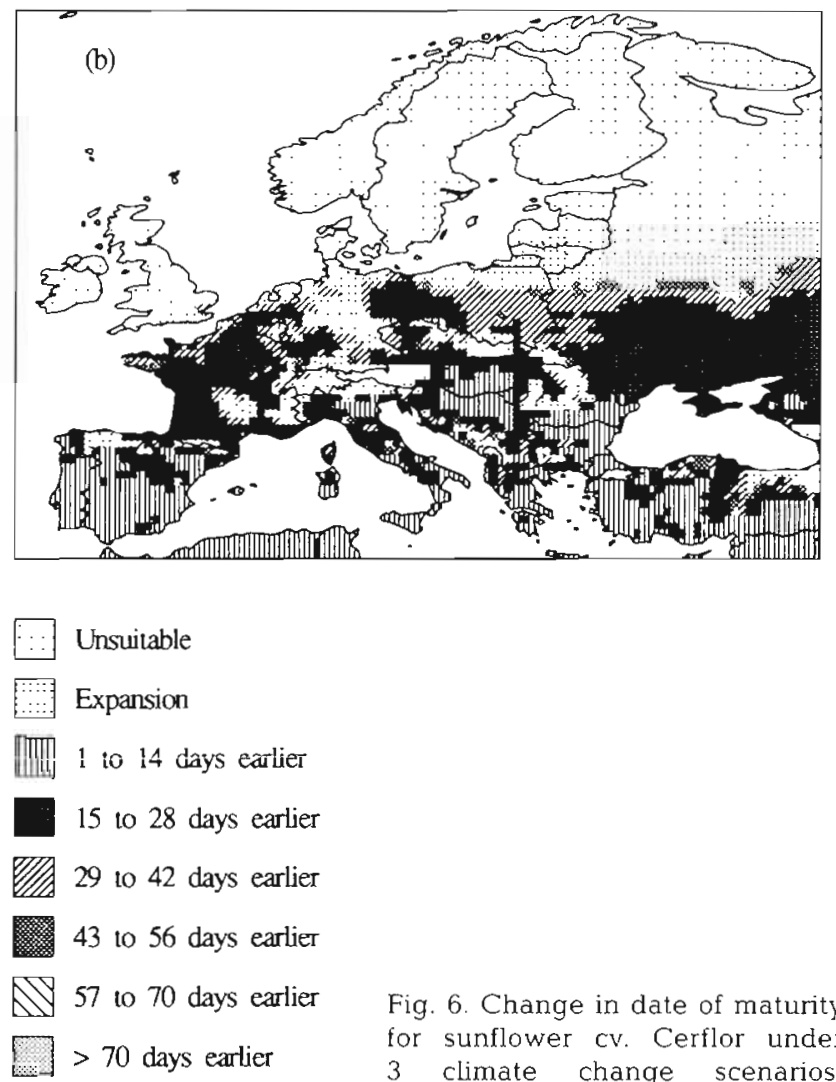

Fig. 6. Change in date of maturity for sunflower cv. Cerflor under 3 climate change scenarios: (a) UKHI, (b) UKTR31-40, and (c) UKTR66-75

for all scenarios. The equilibrium scenario (UKHI) causes the greatest northwards and eastwards progression in suitability into mid-Scandinavia and most of Russia because of its higher temperature predictions. The area of suitability for sunflower extends northwards into southern Scotland and Scandinavia for the UKHI scenario, into northern Germany, southern England and northern Poland for the earlier transient model decade and into southern Finland, southern Sweden and central England in the last transient model decade.

\subsection{Water-limited yield}

Increases in water-limited winter wheat yields and a mixture of increases and decreases in water-limited sunflower yields are predicted throughout Europe under all scenarios. This is explained by improved rates of assimilation and transpiration from elevated $\mathrm{CO}_{2}$ which compensate for the negative effects of a shorter grain/seed filling period and of increased PET in all regions for wheat, but in only some regions for sunflower. The patterns of yield change are further influenced by the scenario projections of future 

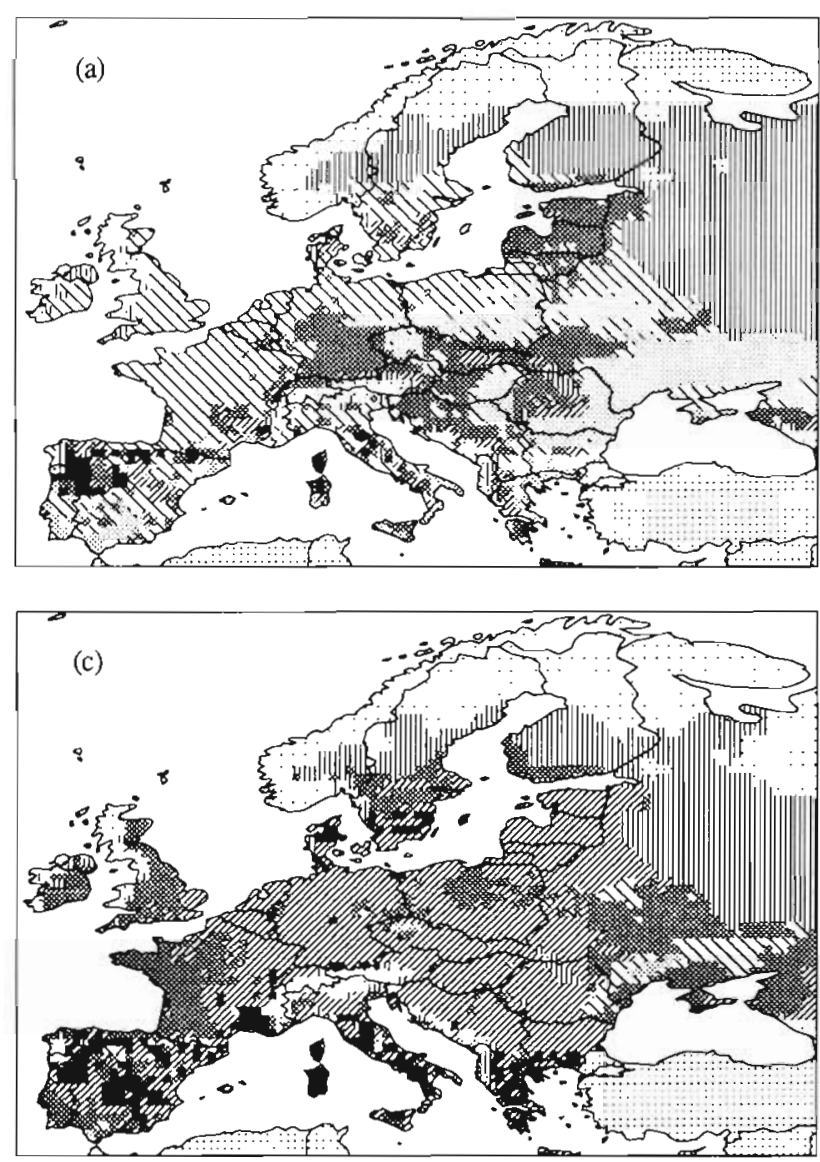

changes in precipitation. In general, decreases in precipitation across southern Europe and increases in precipitation in northern and eastern Europe are predicted for all scenarios. These factors result in the following changes in water-limited yield for winter wheat and sunflower.

Changes in water-limited yield for wheat and sunflower are shown in Figs. 7 \& 8. Results are highly spatially variable and, hence, only broad patterns of change are described. The largest increases in wheat yields are generally observed in central Europe and the lowest in western Europe and Scandinavia. Predictions for southern Europe are highly variable both within the region and between the scenarios. The patterns of change in sunflower water-limited yields vary between the equilibrium and transient scenarios. In the equilibrium scenario the largest decreases in yield are found throughout central Europe and yield increases only occur in southwestern Europe. The transient scenarios show moderate increases in yield across northern and eastern Europe and highly variable predictions for southern Europe. Both wheat and sunflower show more positive yield responses to the transient scenarios (UKTR) compared to the equilibrium scenario (UKHI).

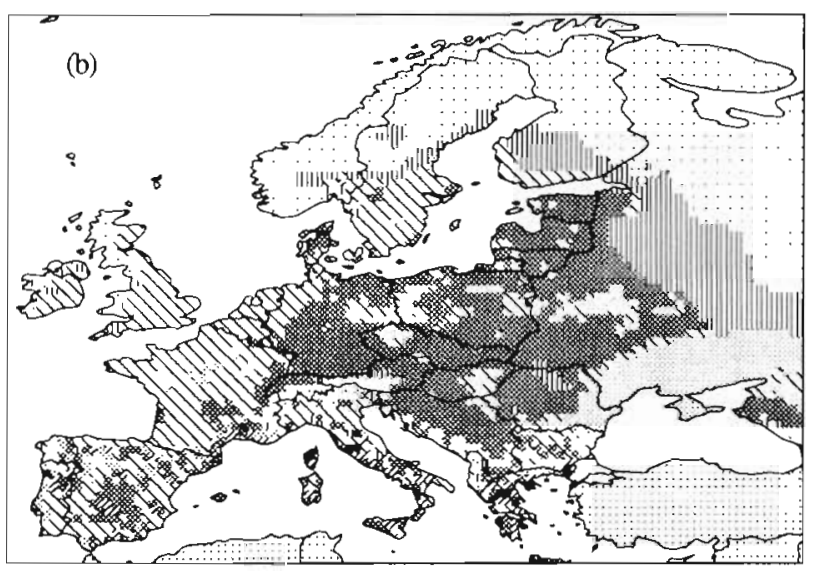

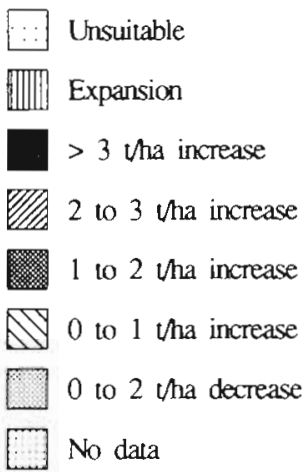

Fig. 7 Change in water-limited yield for winter wheat cv. Avalon under 3 climate change scenarios: (a) UKHI, (b) UKTR31-40, and (c) UKTR66-75

\section{DISCUSSION}

The aim of this paper was to develop regional models based on mechanistic principles which enable investigation of the spatial variability of crop responses to climate change. Europe-wide models of winter wheat and sunflower productivity were developed. The models were compared with observed and experimental data reported in the literature and from agricultural experimental stations. Simulated phenology and yield agreed well with reported values across a variety of scales from point observations to country averaged statistics. More importantly, the large-scale models capture the correct spatial pattern of winter wheat and sunflower productivity across Europe.

An illustration of the degree to which the Euro' models encapsulate spatial variability in crop responses is shown in Fig. 9. This figure shows a comparison between the EuroWheat model and 4 site-specific wheat models [AFRCWHEAT2 (Porter 1984, 1993, Weir et al. 1984), NWHEAT (Groot 1993), Sirius (Jamieson et al. 1996) and CERES-Wheat (Ritchie \& Otter 1985, Godwin et al. 1990)] at 2 sites in Europe (Rothamsted, UK, and Seville, Spain). Results for EuroWheat are given for the $0.5^{\circ}$ latitude/longitude 

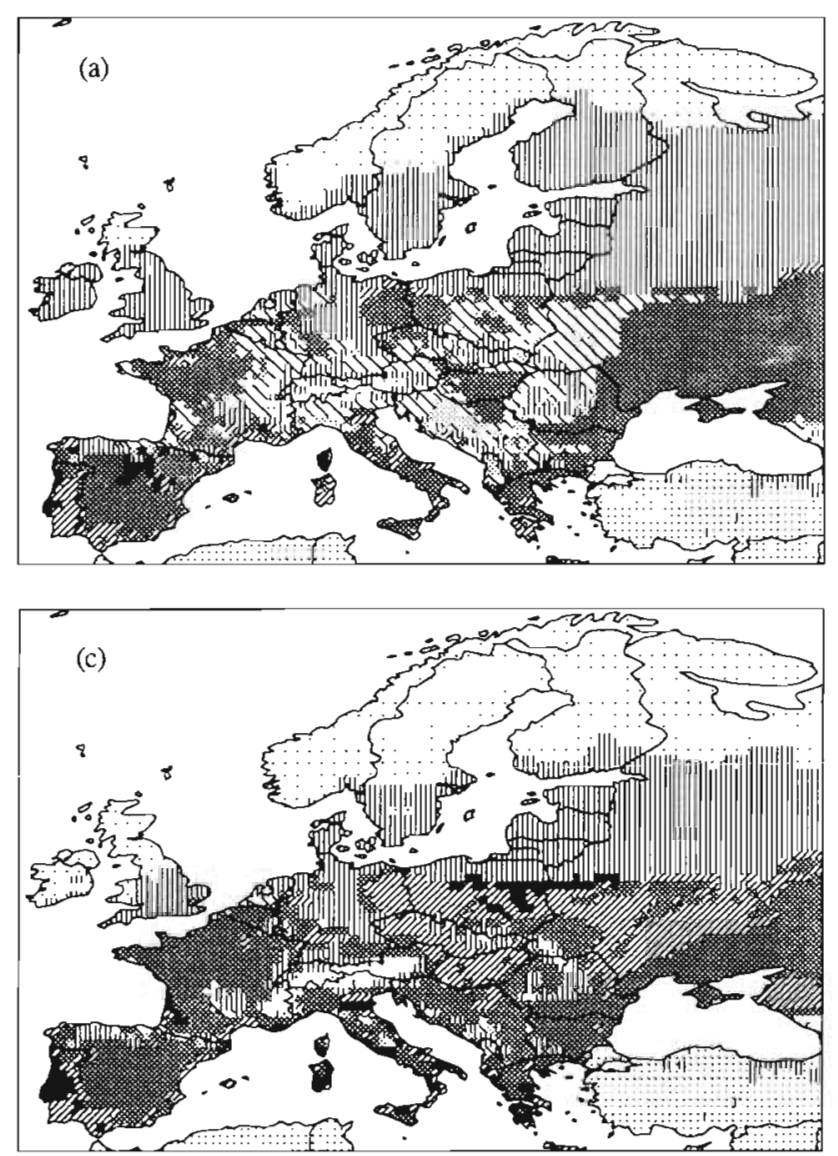

grid cell which contains each site and the 8 surrounding cells (Fig. $9 \mathrm{a}, \mathrm{c}$ ). Results from the site-specific models would only be expected to be similar to those from the spatially explicit EuroWheat model if the site is representative of the region. This is close to the case at Rothamsted as the climate and topography of this area of southern England are fairly homogeneous. Fig. 9a shows that predicted yields vary only slightly between the 9 cells and correspond to yields predicted using the site-specific models at Rothamsted. On the other hand, Seville is located in a river valley with mountain ranges to the north and east. This region has a highly variable topography in which elevations range from sea level to $1830 \mathrm{~m}$ within the 9 cells. This variability is reflected in the predictions of water-limited yields from the Eurowheat model which vary from 3.6 to $10.2 \mathrm{t} \mathrm{ha}^{-1}$ between the 9 cells for the baseline climate (Fig. 9c). This spatial variability is not captured using the site models where the average yield for current climatic conditions is $6.5 \mathrm{t} \mathrm{ha}^{-1}$ for the 4 models (Fig. 9d). Note that there is also considerable variability between sitespecific models at both sites (see Semenov et al. 1996 , Wolf et al. 1996).

The effects of the climate change scenarios on the EuroWheat model show a similar direction and magni-

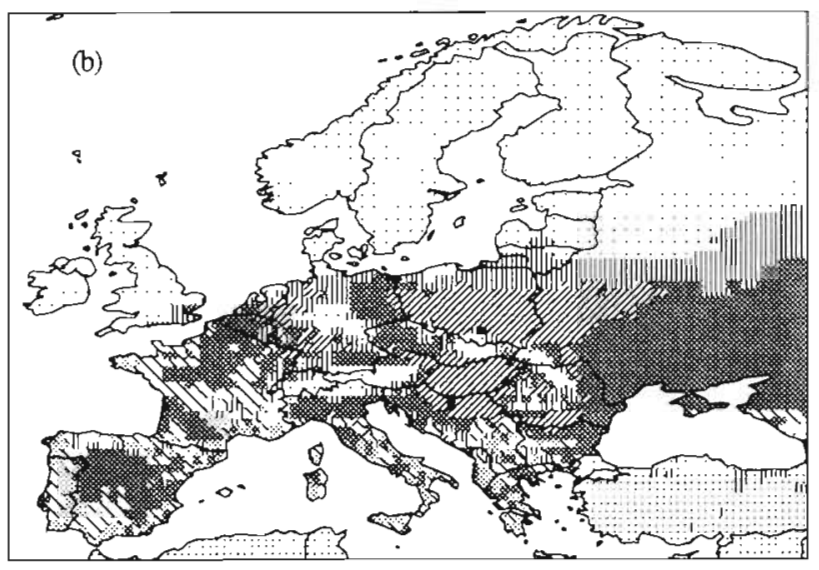

Unsuitable

Expansion

$>1$ ina increase

0 to 1 tha increase

0 to 1 tha decrease

1) 1 to 2 tha decrease

$>2$ tha dectease

No data

Fig. 8. Change in water-limited yield for sunflower cv. Cerflor under 3 climate change scenarios: (a) UKHI, (b) UKTR31-40, and (c) UKTR66-75

tude of response to that exhibited by the site-based models (Fig. 9). For example, at Rothamsted all models show small increases in yield for the UKTR31-40 and UKHI scenarios (of approximately $0.5 \mathrm{tha}^{-1}$ ) and larger increases in yield for the UKTR66-75 scenario (ranging from 1 to $1.5 \mathrm{t} \mathrm{ha}^{-1}$ ). At Seville, similar responses occur for the 2 transient scenarios to those described at Rothamsted. However, both the EuroWheat model and the site-based models predict dramatic yield decreases for the UKHI equilibrium scenario. Therefore, the use of mechanistic principles in the Euro' large-scale models appears to emulate the performance of the more complex and data intensive site-specific models.

A summary of predicted changes in water-limited yield for winter wheat and sunflower for 4 European regions is shown in Table 5. Area averaged wheat yields increase for all regions and scenarios. Conversely, water-limited yields for sunflower decrease in some regions under all climate change scenarios. Marginal increases in area averaged sunflower yield are observed for the UKTR66-75 scenario in all regions. This is consistent with the response of wheat where the largest yield increases are found for the last model decade of the transient scenario (66-75). The least beneficial effects in the case of wheat or the most neg- 
(a)

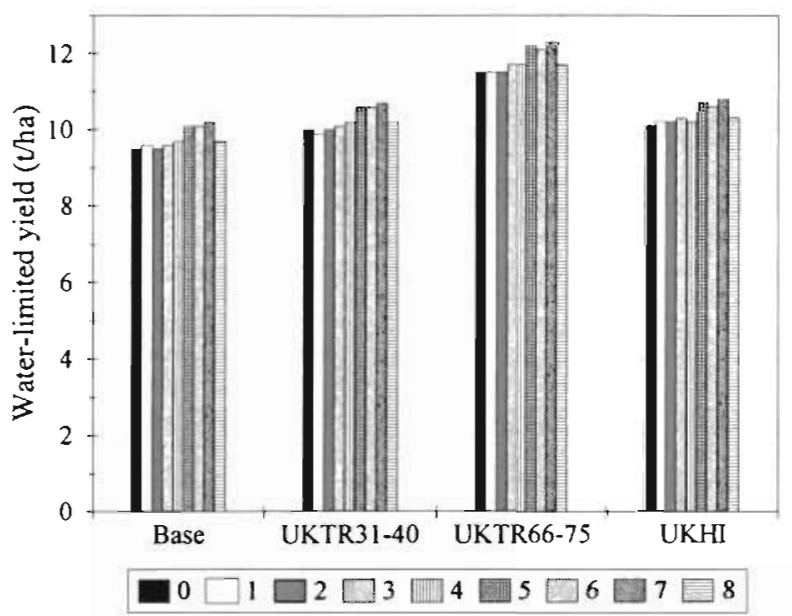

(c)

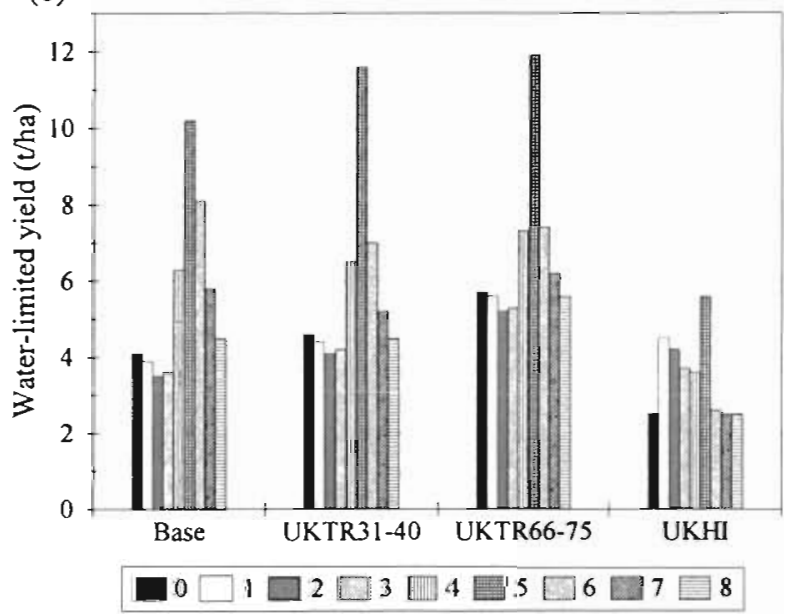

(b)

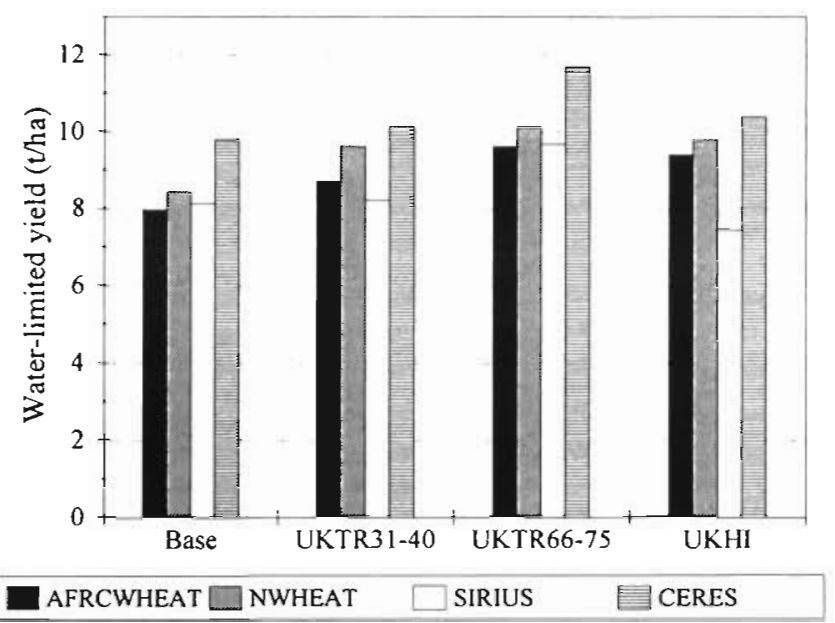

(d)

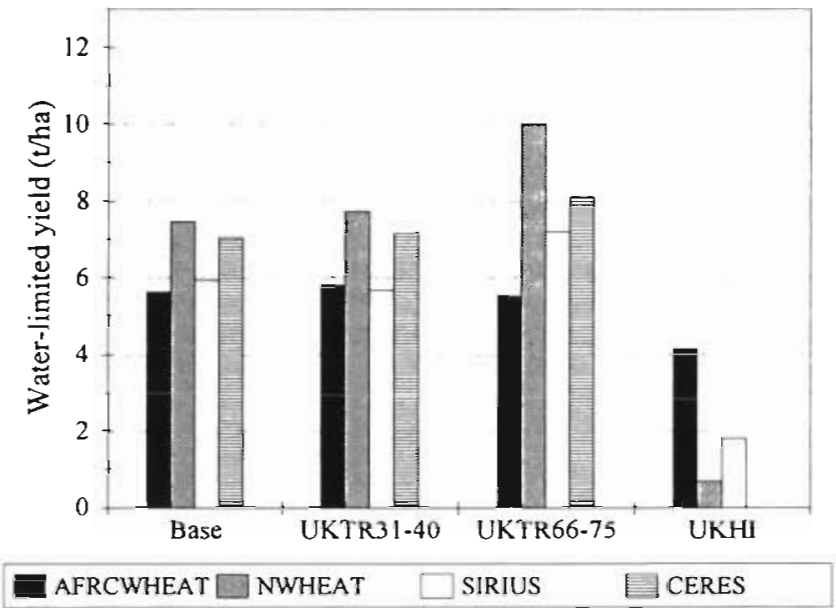

Fig. 9. Comparison between EuroWheat and 4 site-specific wheat models (AFRCWHEAT2, NWHEAT, Sirius and CERES-Wheat): (a) \& (c) results using the EuroWheat model for the 9 grid cells surrounding the sites of Rothamsted, UK, and Seville, Spain, respectively $(0$ indicates the grid cell containing the site, 1-8 indicates cells numbered in a clockwise direction from the top left corner); (b) \& (d) mean results using the site-specific models at Rothamsted and Seville, respectively. Note: the CERES-Wheat model at Seville predicted crop failure for the UKHI scenario

ative effects in the case of sunflower occur in the equilibrium scenario (UKHI). Given a mean climate sensitivity and the IS92a emissions scenario, the changes in climate projected in the UKTR31-40 and UKTR66-75 scenarios would be realised in the years 2023 and 2064 respectively. This implies a rate of increase in wheat yields of $0.2 \mathrm{t} \mathrm{ha}^{-1}$ decade $^{-1}$ from 1990 to 2023 and $0.36 \mathrm{t} \mathrm{ha}^{-1}$ decade $^{-1}$ from 2023 to 2064 across Europe. The corresponding rate of change in sunflower yields is smaller than for wheat. On average, Europe would experience a decrease in sunflower yields of $0.05 \mathrm{tha}^{-1}$ from 1990 to 2023 followed by an increase of $0.05 \mathrm{t} \mathrm{ha}^{-1}$ decade $^{-1}$ from 2023 to 2064

These differences in crop response can be explained by a number of interacting factors. Higher temperatures cause increased developmental rates and, hence, shorter growing period length. A shorter grain filling (wheat) or seed filling (sunflower) period results in less time to accumulate dry matter and, thus, lower yields. On the other hand, elevated concentrations of atmospheric $\mathrm{CO}_{2}$ cause increased assimilation rates and, hence, higher potential yields, counteracting the negative effects of a shorter growing period. Furthermore, in water-limited situations the interaction between increased PET, either increased or decreased precipitation (depending on the scenario) and improved water use efficiency from elevated $\mathrm{CO}_{2}$ further complicates the simulated change in yield. In the case of wheat, relatively small decreases were predicted in the length of the growing period and the beneficial effects from $\mathrm{CO}_{2}$ were large, compared to sunflower. This resulted in moderate to large increases in yield for all climate 
Table 5. Mean water-limited winter wheat and sunflower yields (and standard deviation) for 4 regions of Europe for the current climate (1961-1990) and 3 climate change scenarios (in $\mathrm{t} \mathrm{ha}^{-1}$ )

\begin{tabular}{|c|c|c|c|c|c|}
\hline \multirow{2}{*}{$\begin{array}{l}\text { Emissions scenario } \\
\left(\mathrm{CO}_{2} \text { in ppmv) }\right.\end{array}$} & \multirow[t]{2}{*}{ GCM scenario } & \multicolumn{4}{|c|}{ Region } \\
\hline & & Europe $^{d}$ & E.U. & Northern E.U. & Southern E.U. ${ }^{d}$ \\
\hline \multicolumn{6}{|l|}{ Wheat } \\
\hline Base (353) & Base & $8.07(2.34)$ & $7.77(2.86)$ & $9.25(1.22)$ & $5.94(3.23)$ \\
\hline $2 \times \mathrm{CO}_{2}(560)$ & UKHI & $8.43(2.55)$ & $8.50(2.86)$ & $9.70(1.37)$ & $6.79(3.49)$ \\
\hline IS92a (454) & UKTR31-40 & $8.74(2.50)$ & $8.61(2.69)$ & $9.86(1.33)$ & $6.91(3.09)$ \\
\hline IS92a (617) & UKTR66-75 & $10.21(2.22)$ & $10.17(2.62)$ & $11.13(1.37)$ & $8.83(3.28)$ \\
\hline \multicolumn{6}{|l|}{ Sunflower } \\
\hline Base (353) & Base & $1.53(1.27)$ & $1.36(1.22)$ & $2.41(1.09)$ & $0.78(0.84)$ \\
\hline $2 \times \mathrm{CO}_{2}(560)$ & UKHI & $0.93(0.77)$ & $0.98(0.83)$ & $1.46(0.77)$ & $0.76(0.74)$ \\
\hline IS92a (454) & UKTR31-40 & $1.37(1.11)$ & $1.24(1.05)$ & $1.94(1.11)$ & $0.86(0.78)$ \\
\hline IS92a (617) & UKTR66-75 & $1.59(1.22)$ & $1.47(1.16)$ & $2.15(1.11)$ & $1.10(1.01)$ \\
\hline 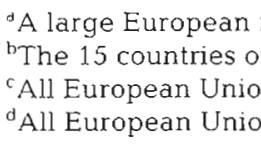 & $\begin{array}{l}\text { extending from } \\
\text { ons noan Union } \\
\text { ons south of } 45^{\circ} \\
\text { ons }\end{array}$ & ${ }^{\circ} \mathrm{N}$ and $11^{\circ} \mathrm{W}$ & ${ }^{\circ} \mathrm{E}$ & & \\
\hline
\end{tabular}

change scenarios. Alternatively, the length of the growing period for sunflower was reduced dramatically and the direct effects of $\mathrm{CO}_{2}$ were less than for wheat. This resulted in moderate decreases in yield for sunflower for most scenarios. The differences between the responses of the 2 crop types can be explained as follows. Firstly, the rate of progress of winter wheat to maturity is repressed in the Eurowheat model through the interaction of photoperiod and vernalization during the overwintering phase of development. Such interactions are not present in the EuroSunfl model, making it more sensitive to increases in temperature. Secondly, experimental evidence suggests that sunflower benefits to a lesser extent from increased concentrations of atmospheric $\mathrm{CO}_{2}$ than winter wheat.

Both crops exhibit similar spatial patterns of response to the climate change scenarios. The lowest yield increases or the highest yield decreases are observed in western Europe and parts of southern Europe. The greatest increases in yield occur in central, eastern and parts of southern Europe. Lowest yield increases for wheat are centred over France, the United Kingdom and the Ukraine, whilst for sunflower the largest yield decreases cover France, Spain, Italy and the countries of southeastern Europe. The most positive changes in wheat and sunflower yield are focused over Germany, Poland, Czech Republic, Hungary, western Russia and scattered areas of southern Europe. A key factor determining the spatial variability of crop response may be the pattern of precipitation change projected by the GCMs. All the climate scenarios are generally wetter in northeastern Europe and drier in southwestern Europe which may explain the more positive results derived for central and eastern regions of Europe, compared with western and southern regions. Predicted changes in yield for southern Europe are highly variable, showing both yield increases and decreases within small regions. In some regions of southern Europe increases in yield occur because the growing period is reduced so that the period when the crop demands most water is shortened and no longer coincides with a time of minimum water availability.

There are many uncertainties in projections of future climate change from GCMs which must be considered when interpreting impacts. The analyses described in this paper are based on 2 GCM experiments (UKHI and UKTR), but both crop models have been applied to comparable scenarios constructed from an alternative transient GCM experiment [Geophysical Fluid Dynamics Laboratory (GFDL), Princeton University, USA; Manabe et al. 1991, 1992]. Only minor differences were found between the impacts of the UKTR and GFDL scenarios. Specifically, increases in winter wheat yield were very slightly greater in the GFDL scenarios, particularly in southern Europe. For sunflower more positive changes in water-limited yield tended to be found in the GFDL scenario for the early model decade, but not for the later decade.

The method presented here is limited by the temporal and spatial scale of available data. The use of monthly data meant it was not possible to examine the effects of extreme climatic events on wheat and sunflower. Time series of climatic data were not available which prevented analyses of interannual variability in crop yields. The spatial climatic database for Europe is currently being developed to include time series information for all variables necessary to calculate optimum 
crop yields (E. Barrow pers. comm.). Hence, future research will employ the spatial models to investigate changes in year-to-year variability in production. Spatially detailed soils and management data were not available across the large European region and, hence, crops were assumed to be cultivated under rain-fed conditions with no nutrient limitations. Pests, weeds and diseases were also not included in the models.

To alleviate negative yield changes for maximise positive changes) farmers will optimise their management practices to adapt to changing climatic and atmospheric conditions by, for example, changing to an earlier sowing date or to a variety better suited to a warmer growing season. The next phase of research will consider possible adaptive strategies which can either further improve yields (wheat) or maintain current production levels (sunflower) under climate change.

Acknowledgements. We acknowledge several scientists for support during this study: John Porter and Mikhail Semenov for provision of wheat varietal parameters and expert advice on the wheat modelling work; Robert Slade of PANNAR (UK) Limited and F. Michaux of Semences CARGILL for provision of sunflower trials data; A. Merrien for helpful suggestions on the sunflower modelling work; Elaine Barrow for provision of the scenarios of climate change; Mikhail Semenov for the AFRCWHEAT and Sirius model runs; Joost Wolf for the NWHEAT model runs; and Ana Iglesias for the CERES-Wheat model runs. Thanks are also due to our colleagues at the Environmental Change Unit, notably Tom Downing, Paul Brignall, John Orr and Megan Gawith for support and helpful comments on the manuscript. This work was conducted for the Environment Programme of the European Commission (Contract number: EV5V-CT92-0294).

\section{LITERATURE CITED}

Agricultural Census (1975-1990) Central Statistical Office, The Hague

Agricultural Statistics (1970-1990) Department of Agriculture, Copenhagen

Agricultural Statistics - United Kingdom (1975-1990) A publication of the govermment statistical service. Ministry of Agriculture, Fisheries and Food, The Scottish Office Agriculture and Fisheries Department, Department of Agriculture for Northern Ireland and Welsh Office Agriculture Department, HMSO, London

Barraclough PB, Kuhlmann $H$, Weir AH (1989) The effects of prolonged drought and nitrogen fertiliser on root and shoot growth and water uptake by winter wheat. J Agron Crop Sci 163:352-360

Barrow E, Hulme M (1995) Construction of scenarios of climate change and climatic variability at the site and regional scales: construction of regional scale scenarios. In: Harrison PA, Butterfield RE, Downing TE (eds) Climate change and agriculture in Europe. Assessment of impacts and adaptation. Research Report 9, Environmental Change Unit, University of Oxford, p 21-30

Barrow E, Hulme Mi, Semenov MA (1996) The effect of using different methods in the construction of climate change scenarios: examples from Europe. Clim Res 7:195-211
Bindi M, Fibbi L, Gozzini B, Orlandini S, Miglietta F (1996) Modelling the impact of future climate scenarios on yield and yield variability of grapevine. Clim Res 7:213-224

Bindi M, Maracchi G. Miglietta F (1993) Effects of climate change on the ontomorphogenetic development of winter wheat in Italy. In: Kenny GJ, Harrison PA, Parry ML (eds) The effect of climate change on agricultural and horticultural potential in Europe. Research Report 2, Environmental Change Unit, University of Oxford, p 67-92

Broekhuizen S (1965) Agroecological atlas of cereal growing in Europe. Volume II: Atlas of the cereal growing areas in Europe. PUDOC, Wageningen

Brooks CEP (1943) Interpolation tables for daily values of meteorological elements. Q J R Meteorol Soc 69:160-162

Bunting AH, Dennett MD, Elston J, Speed CB (1982) Climate and crop distribution. In: Blaxter K, Fowder L (eds) Food, nutrition and climate. Applied Science Publishers, London, p 43-74

Carter TR, Parry ML, Harasawa H, Nishioka S (1994) IPCC technical guidelines for assessing climate change impacts and adaptations. Working Group II of the Intergovernmental Panel on Climate Change, Department of Geography, University College, London, and Center for Global Environmental Research, Tsukuba

Carter TR, Parry ML, Porter JR (1991) Climatic change and future agroclimatic potential in Europe. Int J Climatol 11: $251-269$

Chapman SC, Hammer GL, Holger M (1993) A sunflower simulation model: I. Model development. Agron J 85:725-735

Crofts HJ (1989) On defining a winter wheat. Euphytica 44: $225-234$

Doyle AD (1975) Influence of temperature and daylength on phenology of sunflowers in the field. Aust $J$ Exp Agric Anim Husb 15:88-92

Easterling WE, Crossen PR, Rosenberg NJ, McKenney MS, Katz LA, Lemon KM (1993) Agricultural impacts and responses to climate change in the Missouri-lowaNebraska-Kansas (MINK) region. Clim Change 24:23-61

EUROSTAT (1992) Regio regional databank. Statistical Office of the European Communities, Luxembourg

FAO (1986) Early agrometeorology crop yield assessment. Plant Production and Protection Paper 73, Food and Agriculture Organisation of the United Nations, Rome

FAO Production Yearbooks (1975-1990) Food and Agriculture Organisation of the United Nations, Rome

Godwin D, Ritchie J, Singh U. Hunt L (1990) A user's guide to CERES-Wheat-V2.10. Simulation manual IFDC-SM-2. International Fertilizer Development Center, Muscle Shoals, AL

Goudriaan J, Unsworth MH (1990) Implications of increasing carbon dioxide and climate change for agricultural productivity and water resources. In: Kimball BA, Rosenberg NJ, Allen LH Jr (eds) Impact of carbon dioxide, trace gases and climate change on global agriculture. ASA Spec Publ 53:71-82

Goyne PJ, Schneiter AA (1987) Photoperiod influence on development in sunflower genotypes. Agron J 79:704-709

Goyne PJ, Schneiter AA (1988) Temperature and photoperiod interactions with the phenological development of sunflower. Agron J 80:777-784

Groenendijk H (1989) Estimation of the water-holding capacity of soils in Europe. The compilation of a soil dataset. Simulation Report CABO-TT 19, Department of Theoretical Production Ecology, Agricultural University, Wageningen

Groot JJR (1993) NWHEAT; nitrogen balance in a system of winter wheat and soil. In: Engel T, Klöcking B, Priesack E, 
Schaaf $T$ (eds) Simulationsmodelle zur Stickstoffdynamik, Analyse und Vergleich. Agrarinformatik, Band 25, Ulmer, Stuttgart, p 397-411

Hammer GL, Goyne PJ, Woodruff DR (1982) Phenology of sunflower cultivars. III. Models for prediction in field environments. Aust J Agric Res 33:263-274

Harrison PA (1994) A method for scaling up the AFRCWHEAT phenology model to assess the broadscale implications of climate change on wheat development. Paper presented at the Workshop on Climate Change and Agriculture in Europe, 23-26 September 1994, Halkidiki, Greece. Third CLAIRE Workshop Report, Environmental Change Unit, University of Oxford, p 146-153

Harrison PA, Butterfield RE, Gawith MJ (1995) Modelling the effects of climate change on crops at the regional scale: effects on winter wheat, sunflower, onion and grassland. In: Harrison PA, Butterfield RE, Downing TE (eds) Climate change and agriculture in Europe: assessment of impacts and adaptation. Research Report 9, Environmental Change Unit, University of Oxford, p 330-385

Hulme $M$, Conway D, Jones PD, Jiang T, Barrow EM, Turney C (1995) Construction of a 1961-1990 European climatology for climate change modelling and impact applications. Int J Climatol 15:1333-1363

Jamieson PD (1989) Modelling the interaction of wheat production and the weather. In: Johnson RWM (ed) Integrated systems analysis and climate impacts. Proceedings of a Workshop on Systems Analysis, Wellington, November 1989. Rural Policy Unit, MAF-Technology, Wellington, p $133-140$

Jamieson PD, Semenov MA, Brooking IR, Francis GS (1996) Sirius: a mechanistic model of wheat response to environmental variation. Field Crops Res (in press)

Jamieson PD, Wilson DR (1988) Agronomic uses of a model of wheat growth, development and water use. Proc Agron Soc NZ 18:7-10

Kenny GJ, Harrison PA (1992) The effects of climate variability and change on grape suitability in Europe. J Wine Res 3:163-183

Kiniry JR, Blanchet $R$, Williams JR, Texier $V$, Jones CA, Cabelguenne $M$ (1992) Sunflower simulation using the EPIC and ALMANAC models. Field Crops Res 30: $403-4.23$

Leggett J, Pepper WJ, Swart RJ (1992) Emissions scenarios for the IPCC: an update. In: Houghton JT, Callander BA, Varney SK (eds) Climate change 1992: the supplementary report to the IPCC scientific assessment. Cambridge University Press, Cambridge, p 69-96

Manabe S, Spelman MJ, Stouffer RJ (1992) Transient responses of a coupled ocean-atmosphere model to gradual changes of atmospheric $\mathrm{CO}_{2}$. Part II: Seasonal response. J Clim 5:105-126

Manabe S, Stouffer RJ, Spelman MJ, Bryan K (1991) Transient responses of a coupled ocean-atmosphere model to gradual changes of atmospheric $\mathrm{CO}_{2}$. Part I: Annual mean response. J Clim 4:785-818

Merrien A (1986) Cahier technique physiologie tournesol. CETIOM, Paris

Mitchell JFB, Manabe S, Meleshko V, Tokioka T (1990) Equilibrium climate change and its implications for the future. In: Houghton JT, Jenkins GJ, Ephraums JJ (eds) Climate change: the IPCC scientific assessment. Cambridge University Press, Cambridge, p 131-172

Mitchell RAC, Lawlor DW (1993) The effect of increased temperature and $\mathrm{CO}_{2}$ concentration on winter wheat: test of model prediction. J Exp Bot 44(Suppl):15
Monsi M, Saeki T (1953) Über den Lichtfaktor in den Pflanzengesellschaften und seine Bedeutung für die Stoffproduktion. Jpn J Bot 14:22-52

Mukula J, Rantanen O (1989) Climatic risks to the yield and quality of field crops in Finland. IV. Winter wheat 1969-1986. Ann Agric Fenn 28:13-19

Murphy JM (1995) Transient response of the Hadley Centre coupled ocean-atmosphere model to increasing carbon dioxide. Part I: Control climate and flux adjustment. J Clim 8:36-56

Murphy JM, Mitchell JFB (1995) Transient response of the Hadley Centre coupled ocean-atmosphere model to increasing carbon dioxide. Part II: Spatial and temporal structure of the response. J Clim 8:57-80

Narciso G, Ragni P, Venturi A (1992) Agrometeorological aspects of crops in Italy, Spain and Greece: a summary review of common and durum wheat, barley, maize, rice, sugarbeet, sunflower, soybean, rape, potato, tobacco, cotton, olive and grape crops. Publication EUR 14124 of the Office for Official Publications of the European Communities, Luxembourg

Nonhebel S (1993) The effects of changes in temperature and $\mathrm{CO}_{2}$ concentration on spring wheat yields in The Netherlands. Clim Change 24:311-329

Orr JL, Brignall AP (1995) Methods for site and regional scale integration of crop model results. In: Harrison PA, Butterfield RE, Downing TE (eds) Climate change and agriculture in Europe. Assessment of impacts and adaptation. Research Report 9, Environmental Change Unit, University of Oxford, p 391-401

Papajorgji P, Jones JW, Peart RM, Curry B (1994) Using crop models and geographic information systems to study the impact of climate change in the south-eastern USA. Soil Crop Sci Soc Fla Proc 53:82-86

Penman HL (1948) Natural evaporation from open water, bare soil, and grass. Proc R Soc Lond A 193:120-146

Porter JR (1984) A model of canopy development in winter wheat. J Agric Sci 102:383-392

Porter JR (1993) AFRCWHEAT2: a model of the growth and development of wheat incorporating responses to water and nitrogen. Eur J Agron 2:69-82

Porter JR, Kirby EJM, Day W, Adam JS, Appleyard M. Ayling S, Baker CK, Beale P, Belford RK, Biscoe PV, Chapman A, Fuller MP, Hampson J, Hay RKM, Hough MN, Matthews S, Thompson WJ, Weir AH, Willington WBA, Wood DW (1987) An analysis of morphological development stages in Avalon winter wheat crops with different sowing dates and at ten sites in England and Scotland. J Agric Sci 109 $107-121$

Poorter $\mathrm{H}$ (1993) Interspecific variation in the growth response of plants to an elevated $\mathrm{CO}_{2}$ concentration Vegetatio 104/105:77-97

Reinink K, Jorritsma I, Darwinkel A (1986) Adaption of the AFRC wheat phenology model for Dutch conditions. Neth J Agric Sci 34:1-13

Ritchie J, Otter S (1985) Description of and performance of CERES-Wheat: a user-orientated wheat yield model. In Willis WO (ed) ARS wheat yield project. Department of Agriculture, Agricultural Research Service, ARS-38 Washington, DC, p 159-175

Russell G. Wilson GW (1994) An agro-pedo-climatological knowledge-base of wheat in Europe. Publication EUR 15789 EN of the Office for Official Publications of the European Communities, Series 'Agriculture', Luxembourg

Semenov MA, Porter JR, Delécolle R (1993) Simulation of the effects of climate change on growth and development of wheat in the UK and France. In: Kenny GJ, Harrison PA, 
Parry ML (eds) The effect of climate change on agricultural and horticultural potential in Europe. Research Report 2, Environmental Change Unit, University of Oxford, p 121-136

Semenov MA, Wolf J, Evans LG, Eckersten H, Iglesias A (1996) Comparison of wheat simulation models under cllmate change. II. Application of climate change scenarios Clim Res 7:271-281

Statistics Sweden (1975-1990) Örebro

Tyree MT, Alexander JD (1993) Plant water relations and the effects of elevated $\mathrm{CO}_{2}$ : a review and suggestions for future research. Vegetatio 104/105:47-62

Weir AH (1988) Estimating losses in the yield of winter wheat as a result of drought in England and Wales. Soil Use Manage 4:33-40

Weir AH, Bragg PL, Porter JR, Rayner JH (1984) A winter wheat crop simulation model without water or nutrient

Editor: G. Esser, Gießen, Germany limitations. J Agric Sci 102:371-382

Wigley TML, Raper SCB (1992) Implications for climate and sea level rise of revised IPCC emissions scenarios. Nature 357:293-300

Wolf $J$, Evans LG, Semenov MA, Eckersten H, Iglesias A (1996) Comparison of wheat simulation models under climate change. I. Model calibration and sensitivity analyses. Clim Res 7:253-270

Wolf J, van Diepen CA (1991) Effects of climate change on crop production in the Rhine basin. DLO-The Winand Staring Centre, Wageningen

Yearbook of Farm Statistics (1986-1990) National Board of Agriculture, Helsinki

Zaffaroni E, Schneiter AA (1989) Water use efficiency and light interception of semi-dwarf and standard height sunflower hybrids grown in different row arrangements. Agron J 81(5):831-836

Manuscript first received: February 1, 1996 Revised version accepted: July 12,1996 